\title{
Challenges to Fight Covid-19 in Douala Metropolitan Town, Cameroon
}

\author{
Sop Sop Maturin Désiré ${ }^{1}$ Henock Blaise Nguendo Yongsi ${ }^{2}$ \\ ${ }^{I}$ Senior Lecturer, Department of Geography, The Higher Teachers' Training College-Bambili, University of Bamenda, Cameroon \\ ${ }^{2}$ Professor, Department of Public Health, Institute of Training and Research in Demography, University of Yaoundé II-Soa,
}

Yaoundé, Cameroon

DOI: https://doi.org/10.51244/IJRSI.2021.8902

\begin{abstract}
Coronaviruses are a family of viruses that can cause illnesses such as the common cold, severe acute respiratory syndrome (SARS) and Middle East respiratory syndrome (MERS). In 2019, a new coronavirus was identified as the cause of a disease outbreak that originated in China. Cases of COVID. 19 have been reported in a growing number of cities worldwide. Cameroon recorded the first case of the Coronavirus on the $6^{\text {th }}$ of March 2020 and thereafter, there was a geometric increase in the number of cases. In response to this, the government announced firm measures in an effort to curb the exponential increase of the Coronavirus cases in the country. Despite the measures, the number of cases has continued to increase, coupled with other unwanted socio-economic phenomenons. The goal of this study is to examine the challenges to fight Covid-19 in Cameroon urban settlements as with the case of Douala metropolitan city. Data used here was derived from a cross-sectional study conducted in Douala metropolitan town from May to July 2020. Desktop study and field investigations were undertaken using a questionnaire survey. It was revealed that during lockdown, the city witnessed an increase in the number of cases, increase of unemployment, increase in domestic violence, increase of mental health problems, increase in other infectious diseases and delays in other treatments. The study recommends the effective follow-up of the measures put in place by the government as well as all the stakeholders, the financial support of enterprises and an aggressive sensitization of the population.
\end{abstract}

Keywords: Covid-19; Lockdown, Domestic violence; Douala, Cameroon

\section{INTRODUCTION}

A n outbreak of a new coronavirus disease that causes respiratory tract infections and can be lethal in humans began in China in December 2019. On 11 March 2020, the World Health Organization (WHO) announced that the current outbreak of the coronavirus disease 2019 (COVID19), a respiratory illness caused by the Severe Acute Respiratory Syndrome Coronavirus 2 (SARS-CoV-2), is a pandemic[1]. This COVID-19 started spreading rapidly to other countries by the of December 2019. By late March 2020, the global death toll had passed 36,200 , with infections rising to more than 755,500 [4]. The first case in Africa was identified in Egypt in February 2020. According to WHO (2020), there were 37393 confirmed cases and 1598 deaths registered in Africa by 30 April 2020. South Africa and Egypt have crossed the 5000 -cases bar. They are followed by Morocco (4 359 cases), Algeria (3 848 cases) and Ghana (2
074 cases)[7]. The first case declared in Cameroon was on 6 March 2020. By 30 April 2020, there were 2069 confirmed cases and 61 deaths registered (MINSANTE, 2020). With the passage of time, new cases have been on the rise, currently making Cameroon one of the African countries most affected by the pandemic[8].The COVID-19 outbreak is spreading very fast every day and more than 4 million people have been actively infected by this virus so COVID-19 restrictions are applied in almost all areas of life. The most basic measure to reduce the spread of coronavirus or to prevent infection is to follow hygiene rules [5]. The measures taken to mitigate the impact of the COVID-19 pandemic have suddenly changed daily human functioning. Social distancing, self isolation, loss of freedom, uncertainty, school and business closings, economic vulnerability and job loss have been some results of the lockdown[2].People worldwide have been told by authorities to stay home to reduce the transmission of coronavirus, and social isolation and domestic quarantine can deepen relationships between family members, intensifying intimacy, affective exchanges, personal ties and previous behaviors, thus becoming a period of emotional growth for all involved[3].Despite the measures taken by the Government in Cameroon, there is an increase in cases and deaths by COVID-19, especially in metropolitan town like Douala. The goal of this study is to highlight the challenges to fight Covid19 in metropolitan cities in sub-Saharan Africa with the case of Douala in Cameroon.

\section{MATERIALS AND METHODS}

\section{Study Area}

The study was conducted in Douala metropolitan town in Cameroon (figure 1). Douala is situated between latitude $4^{\circ} 3^{\prime} 53.77^{\prime \prime}$ North of the Equator and longitude 9 ${ }^{\circ} 41^{\prime} 15.41^{\prime \prime}$ East of the Greenwich meridian. It is a coastal city established on the banks of the river Wouri which divides it in two linked by the Bonaberi bridge. Located approximately $30 \mathrm{~km}$ from the Atlantic Ocean and covers an area of approximately $210 \mathrm{~km}^{2}$ with an approximate population of 3.6 million inhabitants in 2019 giving a population density of about 177.79 inhabitants $/ \mathrm{km}^{2}$. It is bounded to the North by the Mungo Division, to the North East by the Nkam Division, to the South East by the Dibamba River and bounded to the South West by the Atlantic Ocean. One can notice a city with 
great opening to other countries through sea transport. Before coming under German rule in 1884 , the town was also known as Cameroon Towns; thereafter it became Kamerunstadt (Cameroon City), the capital of German Kamerun. It was renamed Douala in 1907 after the name of the natives known as Dua ala Ijaws (Njos), and became part of French Cameroon in 1919.

Douala features a tropical monsoon climate (koppen classification Am) with relatively consistent temperatures throughout the course of the year, though the city experiences somewhat cooler temperatures in July and August. Douala typically features warm and humid conditions with an abundant rainfall of the order of 4000 to $6000 \mathrm{~mm}$ of rainfall per year and an average rainfall of $4200 \mathrm{~mm}$ of rainfall per year, allocating the driest month in December with about $28 \mathrm{~mm}$ of rainfall while the wettest month is August with about $700 \mathrm{~mm}$ of rainfall. The average annual temperature is of the order of $27^{\circ} \mathrm{C}$ and the thermal amplitude is $2.4^{\circ} \mathrm{C}$. Moisture is very high year-round and low-intensity winds are generally southwesterly.

The hydrographic network of the city of Douala is constituted by its principal river Wouri which divides the city in two parts. In addition to the Wouri River, the hydrography of the city of Douala is distributed over nine major hydrographic basins that flow into the Wouri River: Bonassama, Besséke, Bobongo, Mgoua, Kambo, Nsapé, Mbopi, Mbanya and TongoBassa. It can be seen that the beds of these rivers were very small because of the anarchical occupation of the urban space by the populations and the system of waste disposal.

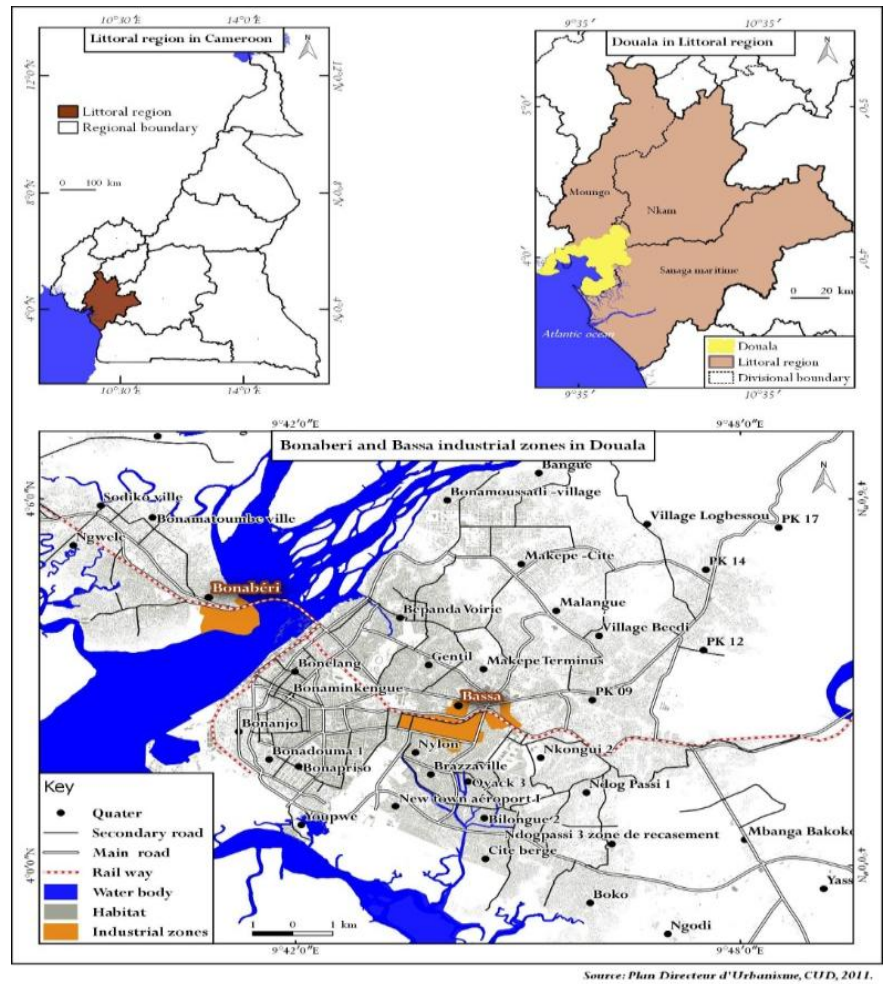

Figure 1: Location of Douala metropolitan town in Cameroon
The city of Douala is established on a set of three low plateaus whose altitudes are between 15 and $22 \mathrm{~m}$ above sea levels; these plateaus are shared by the valleys of Wouri tributaries.The plateaus of Bonanjo and Akwa that slopes gently into the interior and the deidi plateau is separated from the Akwa plateau by the Mbopi valley and is disemboweled by the Nguété Valley tributary of Mboppi. The Bepanda plateau which stretches to the east of the Deido plateau occupies a kind of interfluve between Mbanya and TongoBassa. This plateau of 15 to $20 \mathrm{~m}$ of altitude generally inclines towards North.

Douala is the largest city in Cameroon. It is today a mosaic of ethnic groups that make up Cameroon and owes its recent growth to the rural exodus that has pushed hundreds of thousands of Cameroonians to leave their countryside to settle in the city, coupled with present civil crisis in the North and South West region of Cameroon. The Population of Douala passed from 458426 in 1976 to 1,907479 inhabitants in 2005 and an estimated population of 3,536,000 and 3,663,000 inhabitants $/ \mathrm{km}^{2}$ in 2019 and 2020 respectively with a population growth rate of $3.59 \%$ (Cameroon metro area, 2020). This increase in population can be justified by the presence of numerous industries that serve as a source of job opportunity to the inhabitants. The city of Douala has established itself as the economic capital of the country through its giant sea port which has allowed the development of nearly $80 \%$ of Cameroon's industrial activity. On its own, the port drains more than $95 \%$ of the country's port traffic. The port of Douala-Bonaberi is to this day the main maritime opening of Cameroon and the Economic Community of Central Africa (CEMAC), serving as harbor to closed countries like CAR and Chad. The main products exported are timber (from Cameroon and Central Africa), fruits, and oil. The largest companies in the country have set up their headquarters in Douala rather than in Yaoundé. This is due to the openness of the coast to other countries for fast distribution of goods and services. The city is also home to the headquarters of the African Center for Research on Banana and Plantain that has gained grounds in the National territory.

\section{Study Design}

The study conducted from March 2020 to May 2020, adopted a survey design research. Quantitative methods were in the form of closed ended questionnaire while the qualitative methods included in-depth interviews. Data obtained quantitatively were checked against the findings derived qualitatively from field observations and interviews.

\section{Target Population and Sampling Size}

The targeted populations included the inhabitants living within the metropolitan town of Douala. From this population, a sample size of 300 was randomly chosen. Therefore, 300 questionnaires were distributed around major hotspots of this town. 


\section{Sampling Techniques}

The research adopted Simple random sampling in selecting the sample respondents. This technique gave the population equal chances of being selected or the study therefore avoiding bias.

\section{Data Collection and Management}

Both primary and secondary data sources were used. Primary data was obtained from questionnaires, interviews. Secondary data was obtained from document reviews, web page /blog reviews, and newspapers and archived reports. They were used to generate empirical information for the study

Primary data was collected through the use of techniques like field observations, structured questionnaires and interview guides. These questionnaires were made available to individuals from different backgrounds. The investigations took place in the various hotspots in Douala (Markets, bike and motor park, bars, restaurants and call box). All participants responded to a structured questionnaire provided by the investigator. The questionnaire help us to obtain Information on Covid-19 and respect of government measures for the fight against the illness; Effect of the application of measures for the fight against the disease on respondents' income; Effects of the application of the measures on household violence; - Household adaptive strategies against the effects of government measures.

Secondary data related to corona virus pandemic was obtained from journals and mainly from open access journals.COVID19 case data of the country and of Douala in particular were collected from Website of the Ministry of Public Health and from the tweets of the Minister of the said ministry. Data collected was analyzed with the use of Microsoft excel. Descriptive analyses were implemented for all the data and presented in frequency tables.

\section{Ethical Approval}

The protocol of this study was independently reviewed and approved by the University of Bamenda Ethics Committee. Informed consent was obtained from all participants included in the study. They were then invited to participate voluntarily in the study. They were informed that the study is confidential and that their participation will not affect their care. The agreement was materialized by the signing of the informed consent form.

\section{RESULTS}

\section{Timeline of Covid-19 in Cameroon}

Table 1: Covid-19 timeline in Cameroon since the first case is a matter of great concern.

\begin{tabular}{|l|l|l|}
\hline Date & Event & Response \\
\hline $\begin{array}{l}\text { February 24 } \\
2020\end{array}$ & $\begin{array}{l}\text { Covid-19 } \\
\text { outbreak in } \\
\text { China }\end{array}$ & $\begin{array}{l}\text { Surveillance measures were put in place } \\
\text { by the Government after COVID-19 } \\
\text { appeared in China with detecting the } \\
\text { case. }\end{array}$ \\
\hline
\end{tabular}

\begin{tabular}{|c|c|c|}
\hline $\begin{array}{l}6^{\text {th }} \text { of March } \\
2020\end{array}$ & $\begin{array}{l}\text { Cameroon } \\
\text { recorded the } \\
\text { first case of } \\
\text { the Corona } \\
\text { virus }\end{array}$ & Quarantine and treatment \\
\hline $\begin{array}{l}\text { March } 13 \\
2020\end{array}$ & & $\begin{array}{l}\text { International travel controls- screening } \\
\text { arrivals }\end{array}$ \\
\hline $\begin{array}{l}17^{\text {th }} \text { of March } \\
2020\end{array}$ & $\begin{array}{l}\text { Cameroon } \\
\text { registered } 10 \\
\text { Corona virus } \\
\text { cases }\end{array}$ & $\begin{array}{l}\text { the government announced } 13 \text { firm } \\
\text { measures in an effort to curb the } \\
\text { exponential increase of the Corona } \\
\text { virus cases in the country }\end{array}$ \\
\hline $\begin{array}{l}\text { March 18, } \\
2020\end{array}$ & - & $\begin{array}{l}\text { The government announced } 13 \text { strict } \\
\text { measures to fight Covid-19 }\end{array}$ \\
\hline 29/03/2020 & $\begin{array}{l}\text { Cameroon } \\
\text { registered } 91\end{array}$ & $\begin{array}{l}\text { Active search for passengers on } 2 \\
\text { flights from Europe. }\end{array}$ \\
\hline April 4, 2020 & $\begin{array}{l}\text { Cameroon } \\
\text { was counting } \\
306 \text { confirmed } \\
\text { cases. }\end{array}$ & $\begin{array}{l}\text { Public information campaigns- } \\
\text { coordinated public information } \\
\text { campaign }\end{array}$ \\
\hline April 6, 2020 & - & $\begin{array}{l}\text { Testing policy-testing of anyone } \\
\text { showing Covid-19 symptoms }\end{array}$ \\
\hline April 9, 2020 & - & 7 additional measures \\
\hline $\begin{array}{l}\text { April 13, } \\
2020\end{array}$ & - & $\begin{array}{l}\text { Obligatory wearing of masks and } \\
\text { penalties for defaulters }\end{array}$ \\
\hline $\begin{array}{l}\text { April 15, } \\
2020\end{array}$ & - & $\begin{array}{l}\text { The President of the Republic signed a } \\
\text { decree to reduce and remit the } \\
\text { sentences of some prisoners }\end{array}$ \\
\hline May $1^{\text {st }}, 2020$ & - & $\begin{array}{l}\text { Cameroon Government eased measured } \\
\text { on May1, with public transportation } \\
\text { running as normal, and bars, } \\
\text { restaurants, and leisure facilities } \\
\text { permitted to open past } 6 \text { pm as long as } \\
\text { they adhere to social distancing } \\
\text { measures. } \\
\text { The government also announced tax } \\
\text { forgiveness, financial assistance to } \\
\text { companies, and increases in family } \\
\text { allowances and old age pensions as } \\
\text { compensations for the effects of } \\
\text { COVID-19. }\end{array}$ \\
\hline $\begin{array}{l}8^{\text {th }} \text { of May } \\
2020\end{array}$ & $\begin{array}{l}\text { Cameroon had } \\
3323 \text { cases } \\
\text { and } 139 \\
\text { deaths }\end{array}$ & - \\
\hline May31 $^{\text {st }}, 2020$ & $\begin{array}{l}\text { The } \\
\text { Government } \\
\text { have } \\
\text { confirmed } \\
5904 \text { cases of } \\
\text { COVID-19 in } \\
\text { the country } \\
\text { and } 191 \\
\text { associated } \\
\text { deaths. }\end{array}$ & Cameroon eases COVID-19 Lockdown \\
\hline
\end{tabular}

Source: MINSANTE, 2020

Cameroon recorded the first case of the Coronavirus on the $6^{\text {th }}$ of March 2020 and thereafter, there was a geometric increase in the number of cases. By the $17^{\text {th }}$ of March, Cameroon registered 10 Coronavirus cases and in response to this, the government announced 13 firm measures in an effort to curb the exponential increase of the Coronavirus cases in the country. Despite the measures the number of cases has continued to increase and as of the $8^{\text {th }}$ of May, Cameroon had 3323 cases and 139 deaths.

February 24: Contact tracing 
Surveillance measures were put in place by the Government after COVID-19 appeared in China with detecting the case. It's in this move that Cameroon confirmed the central African State's first case of COVID-19 on March 6, 2020. According to the Minister of Health, it was an imported case discovered in a French citizen of 58 year old who arrived in Cameroon on February 24, 2020. The Patient was immediately placed in solitary confinement in a special hospital in to avoid contact with others. After, health officials started tracing the people the infected man contacted from the airport of departure through the plane's arrival in Cameroon, as well as taxis or cars he used. They also disinfected places he visited.

March 13 2020: International travel controls- screening arrivals

\section{Strict restrictions need a negative test before visa obtains:}

Cameroonian Government have announced on Friday, March 13, that the presentation of a negative COVID-19 test result carry out by an approved institution will be required for the issuance of an entry visa to Cameroon as two COVID-19 cases have been confirmed in Cameroon.

\section{March 18, 2020: School closing-require}

The press release of the Premier minister Head of Government announcing officially to the citizen the presence of COVID-19 in Cameroon was made in this terms: "A few days ago, the World Health Organization announced that the coronavirus has gone from an epidemic to a pandemic, with over 170,000 cases in 146 countries, and about $\mathbf{6 , 5 0 0}$ deaths.

Cameroon, like many States in the world, is not spared by this pandemic. From the very first hours of its emergence, the Government implemented a prevention and response plan aimed at stemming the spread of this epidemic.

Consequently, on the instructions of the Head of State, Paul BIYA, an inter-ministerial consultation was held this Tuesday, 17 March 2020, to assess the situation and identify appropriate actions to be implemented.

At the end of this meeting, the President of the Republic instructed the following measures as from Wednesday 18 March 2020, till further notice was announced by the Premier Minister Head of Government trough a press release in French and English:

1. Cameroon's land, air and sea borders will be closed: consequently, all passenger flights from abroad will be suspended, with the exception of cargo flights and vessels transporting consumer products and essential goods and materials, whose stopover times will be limited and supervised: Cameroonians who wish to come back home should contact our diplomatic representations.

2. The issuance of entry visas to Cameroon at the various airports shall be suspended

3. All public and private training establishments of the various levels of education, from nursery school to higher education, including vocational training centres and professional schools, will be closed;

4. Gatherings of more than fifty (50) persons are prohibited throughout the national territory;

5. School and university competitions, like the FENASSCO and University games are postponed;

6. Under the supervision of administrative authorities, bars, restaurants and entertainment spots will be systematically closed from 6 p.m.;

7. A system for regulating consumer flows will be set up in markets and shopping centres;

8. Urban and inter-urban travel should only be undertaken in cases of extreme necessity;

9. Drivers of buses, taxis and motorbikes are urged to avoid overloading: law enforcement officers will ensure they comply;

10. Private health facilities, hotels and other lodging facilities, vehicles and specific equipment necessary for the implementation of the COVID-19 pandemic response plan in Cameroon may be requisitioned as required, by competent authorities;

11. Public administrations shall give preference to electronic communications and digital tools for meetings likely to bring together more than ten (10) people;

12. Missions abroad of members of Government and public and para-public sector employees are hereby suspended;

13. The public is urged to strictly observe the hygiene measures recommended by the World Health Organization, including regular hand washing with soap, avoiding close contact such as shaking hands or hugging, and covering the mouth when sneezing.

These are difficult but necessary measures to ensure the protection of each and every one and to limit the spread of this pandemic. He also emphasized that In case of need, the public is invited to call the toll-free number 1510 set up for the mobilization of rescue teams. The Government calls on the public not to panic, but to show discipline, solidarity and a sense of responsibility at a time when the whole world is going through difficult times".

April 4, 2020 Public information campaigns-coordinated public information campaign (across traditional and social media)

During this period, Cameroon was counting 306 confirmed cases. The massive door-to-door sensitization and screening campaign against COVID-19 pandemic in the Littoral Region was initiated by the Ministry of Health. Teams from the Ministry of Health were moving from door-to-door to ensure that the whole populations of the Littoral region were sensitized on precautionary measures against COVID-19 pandemic and if deemed necessary they were screened.

April 6, 2020: Testing policy-testing of anyone showing Covid-19 symptoms 


\section{April 9, 20207 additional measures}

1- Compulsory wearing of face mask

2- Local production of local medicine, diagnosis tests, face masks, hand sanitizers

3- Creation of special centers for the treatment of COVID-19 in the headquarters of regions

4- Intensification of diagnosis campaign with the collaboration of Centre Pasteur

5- Sensitization campaign in official's languages and locals languages.

6- Continuation of essentials economic activities in respects of measures put in place on the March 17, 2020

7- Penalty of all defaulters on measures put in place.

\section{April 13, 2020 Obligatory wearing of masks}

From April 13, the Government made obligatory for people to wear face masks whenever appearing in public as part of measures to slow the spread of the coronavirus pandemic.

April 15, 2020: The President of the Republic signed a decree to reduce and remit the sentences of some prisoners

This measure was prevent the spread of COVID-19 in overcrowded prisons

May $1^{\text {st }}, 2020$

Cameroon Government eased measured on May1, with public transportation running as normal, and bars, restaurants, and leisure facilities permitted to open past $6 \mathrm{pm}$ as long as they adhere to social distancing measures. Gatherings of more than 50 people remain prohibithed, and the wearing of face masks is compulsory in public places. Access to public institutions, including government buildings, has been limited.

Cameroon has eased restrictions put in place to curb COVID19, which has caused 1900 confirmed cases and 63 deaths in the country. The Government ease the operation of bar and restaurants after $6 \mathrm{pm}$ with the respects of protective measures.

The government also announced tax forgiveness, financial assistance to companies, and increases in family allowances and old age pensions as compensations for the effects of COVID-19.

As testing capacity increases and isolation and treatment facilities gradually expands in country, the number of positive cases has doubled since May 17 reaching 6752 on June 1st. While the increased testing capacity has resulted in a lower fatality rate, the number of deaths reaches 1999, within each of the ten regions. The Government's decision on April to lift several key preventive measures has increased the risk of propagation of the virus whilst sending a confusing message to the population. Meanwhile, the courageous decision to reopen schools by June $1^{\text {st }}$ raises various practical challenges and faces both parents and teachers reluctance as they fear being infected with COVID. Even though the implementation of the Risk Communication and Community Engagement (RCCE) strategy throughout the country progressively results in a greater awareness amongst urban and rural communities, community's resistances remains the main impediments to slow down the spread of the epidemic. Although now compulsory, the wearing of mask or respect of social distances are hardly complied to both in rural and furthermore in urban areas. Discrimination and stigmatization are rampant when COVID is named. Meanwhile, the lift of major restrictive measures have given ground to all kind of fake news, spurious information and rumors which ultimately further exacerbate the risk of rapid spread of the virus. In April-May, an analysis of the socio-economic impacts of the epidemic has been carried out under UNDP leadership of. According to the results of the analysis, overall, $82.6 \%$ of business leaders reported experiencing a drop-in production. However, this situation is more pronounced in formal sector enterprises than in the formal sector. In terms of impact, almost half of the negatively affected companies say they have recorded a drop of more than $50 \%$ in their production. (OCHA, 2020).

\section{May31 ${ }^{\text {st }}$, 2020: Cameroon eases COVID-19 Lockdown}

Cameroonian Government announced that some measures in place to limit the spread of the coronavirus disease pandemic would be eased from June $1^{\text {st }}$ 2020. In Schools, only examination classes, universities, and training centers, which have been closed since March 17, will be permitted to reopen nationwide provided they adhere to the strict health measures in place. As of May 31, the Government has confirmed 5904 cases of COVID-19 in the country and 191 associated deaths.

Despite the 13 measures taking to stop the spread of COVID19, it appears a majority of citizens in metropolitans cities like Douala was not really following them (table 2).Social distance is more a slogan than a practice: markets remain overcrowded, bikes still carry more than one passenger, buses and taxis still carry more than the government prescribed numbers. On the other citizens, March 17, Cameroon recorded 10 confirm cases of COVID-19, three days later Cameroon had 27 confirmed cases. On the $1^{\text {st }}$ April 2020, the country had 246 cases, six deaths and 10 recoveries.

Cameroon recorded the first case of the Coronavirus on the $6^{\text {th }}$ of March 2020 and thereafter, there was a geometric increase in the number of cases. By the $17^{\text {th }}$ of March, Cameroon registered 10 Coronavirus cases and in response to this, the government announced 13 firm measures in an effort to curb the exponential increase of the Coronavirus cases in the country. Despite the measures the number of cases has continued to increase and as of the $8^{\text {th }}$ of May, Cameroon had 3323 cases and 139 deaths. 
Table 2: Evolution of Covid-19 in Cameroon

\begin{tabular}{|c|c|c|c|c|c|}
\hline \multirow{2}{*}{ Date } & \multicolumn{2}{|c|}{ Confirmed cases } & \multicolumn{2}{|l|}{ Deaths } & \multirow{2}{*}{ Douala } \\
\hline & Cameroon & Douala & Cameroon & Douala & \\
\hline $17 / 03 / 20$ & 05 & 01 & & & - \\
\hline $23 / 03 / 20$ & 40 & 9 & & & - \\
\hline $24 / 03 / 20$ & 72 & & 1 & & - \\
\hline $26 / 03 / 20$ & 70 & 25 & 1 & & - \\
\hline $27 / 03 / 20$ & 75 & & 1 & & - \\
\hline $29 / 03 / 20$ & 91 & 13 & 2 & & Active search for passengers on 2 flights from Europe. \\
\hline $01 / 04 / 20$ & 139 & 7 & & & - \\
\hline $03 / 04 / 20$ & 246 & & 7 & & $\begin{array}{l}\text { Effective screening for COVID- } 19 \text { in the city of Douala at the center of the } \\
\text { Lanquintinie hospital, with an analysis capacity of } 200-300 \text { samples per } \\
\text { day, } 88 \text { beds, } 8 \text { technicians for a population of approximately } 3.6 \text { million } \\
\text { inhabitants. }\end{array}$ \\
\hline $06 / 04 / 20$ & 555 & 7 & & & - \\
\hline $07 / 04 / 20$ & 555 & & 43 & 11 & - \\
\hline $9 / 04 / 20$ & 730 & & 10 & & $\begin{array}{l}\text { Sensitization with } 80366 \text { target households } \\
198640 \text { people were evaluated with } 85,2 \% \text { of acceptance against } 14.8 \% \text { of } \\
\text { refusal out of } 2313 \text { people to be sampled. The purpose of this operation is to } \\
\text { early isolate positive cases from the rest. }\end{array}$ \\
\hline $\begin{array}{l}20 / 04 / 202 \\
0\end{array}$ & 1016 & 400 & 21 & 28 & - \\
\hline $\begin{array}{l}21 / 04 / 202 \\
0\end{array}$ & 1163 & 21 & 42 & & - \\
\hline $26 / 04 / 20$ & 1518 & 83 & 53 & & - \\
\hline $27 / 04 / 20$ & 1621 & 61 & 56 & & Stage 2 , community transmission \\
\hline $28 / 04 / 20$ & 1621 & 438 & 56 & & - \\
\hline $8 / 05 / 20$ & 2077 & 51 & 64 & & - \\
\hline $\begin{array}{l}29 / 05 / 202 \\
0\end{array}$ & 5436 & $\begin{array}{l}1431(65 \\
\text { Health } \\
\text { personnels })\end{array}$ & 177 & 71 & $\begin{array}{l}\text { The entire economic capital is affected by COVID-19, particularly Douala I, } \\
\text { II and Douala V due to the presence of many bars and other nightclubs. } \\
\text { Contrary to the western metropolises where the majority of cases are } \\
\text { recorded in people of the third age. Here it is more people whose age varies } \\
\text { between } 30-39 \text { years who are the most infected, between 5-19 years the } \\
\text { epidemic is marginal and from the age of } 29 \text { years the trend goes up. }\end{array}$ \\
\hline
\end{tabular}

Source: MINSANTE, 2020

Even do the Government has successfully implemented lockdown of all institutes of learning. Other places like markets were still crowded, bars and restaurants were still door closed but in-functional especially for those who depend on these activities as their source of income.

Follow-up of Instructions on Hand Washing in Public Places by the population of Douala

One of the measures taken by the government to fight COVID-19, was the systematic washing of hands with water and soap. After surveys it appears that the population of Douala metropolitan city does not practically respect these measures (table 3).
Table 3: Follow-up of Instructions on Hand Washing in Public Places

\begin{tabular}{|c|c|c|c|c|c|c|}
\hline $\begin{array}{c}\text { Hand } \\
\text { washing }\end{array}$ & Frequency & $\boldsymbol{\%}$ & Male & $\boldsymbol{\%}$ & Female & $\%$ \\
\hline Yes & 102 & 34 & 50 & 49.01 & 52 & 50.99 \\
\hline No & 198 & 66 & 123 & 62.13 & 75 & 37.87 \\
\hline Total & 300 & - & - & - & - & - \\
\hline
\end{tabular}

Source: Field Survey, 2020.

Amongst respondents respecting systematically hand washing measure, $49.01 \%$ are male while $50.99 \%$ are female. In the proportion of respondents who are not respecting the measure, $62.13 \%$ are male and $37.87 \%$ are female. This therefore shows that instructions on hand washing tend to be more followed by women.

\section{Wearing of Face Mask}

Masks have two potential functions. They may protect the wearer of the mask from exposure (personal protective 
equipment), or protect individuals from exposure to respiratory aerosols/droplets from the mask wearer, referred to as source control. The use of masks for the general public has been recommended as one of several COVID-19 pandemic mitigation strategies [9]. As one of the measure to prevent the spread of the Covid-19, the facemask or nose mask has been used widely all around the world and in Cameroon, the government has made it compulsory for it to be worn in public places. But in Douala, the effectiveness of wearing of mask remains problematic (table4).

Table 4: Follow-up of Instructions on mask wearing in Public Places

\begin{tabular}{|c|c|c|c|c|c|c|}
\hline $\begin{array}{c}\text { Wearing } \\
\text { on face } \\
\text { mask }\end{array}$ & Frequency & $\%$ & Male & $\%$ & Female & $\%$ \\
\hline Yes & 85 & 28.33 & 33 & 38.83 & 52 & 61.17 \\
\hline No & 215 & 71.67 & 118 & 54.89 & 97 & 45.11 \\
\hline Total & 300 & - & - & - & - & - \\
\hline
\end{tabular}

Source: Field Survey, 2020.

Table4, revealed that $28.33 \%$ respondents are complying with the measure of wearing on mask in public places, against $71.67 \%$ who are reluctant to do so. Female are more represented than male in the proportion of respondents accepting to wear a mask with $61.17 \%$, while 38.83 male are not complying.

\section{Hand shaking}

Hand shaking is a sign of civility which characterizes human being. But with the Covid-19 pandemic, it was recommended to stop this practice. In Douala metropolitan town this measure was appreciably respected (table 5).

Table 5: Follow-up of Instructions on hand shaking

\begin{tabular}{|c|c|c|c|c|c|c|}
\hline $\begin{array}{c}\text { Instructions } \\
\text { on hand } \\
\text { shaking }\end{array}$ & Frequency & $\boldsymbol{\%}$ & Male & $\boldsymbol{\%}$ & Female & $\boldsymbol{\%}$ \\
\hline Yes & 258 & 86 & 106 & 41.08 & 152 & 58.92 \\
\hline No & 42 & 14 & 18 & 42.86 & 24 & 57.14 \\
\hline Total & 300 & - & - & - & - & - \\
\hline
\end{tabular}

Source: Field Survey, 2020.

It emerges from table 5 that a large majority of the respondents respected the measure of non hand shaking with respectively $86 \%$ compliance against $14 \%$ of non-compliance. Women represented $58.92 \%$ and men $41.08 \%$. The reason behind this follow-up was not really the fear of Covid-19, but the population saw in the new way of greetings a fun time. Particularly the clapping of the feet, the elbow to elbow and the blow and wrist to wrist.

\section{Social distancing}

Social distancing is one of the major measures to fight Covid19 as recommended by WHO and applied by the Cameroonian government. Unfortunately this measure has difficulty in being implemented in Douala metropolitan city (tableau 6).

Table 6: Follow-up of Instructions on social distancing

\begin{tabular}{|c|c|c|c|c|c|c|}
\hline $\begin{array}{c}\text { Social } \\
\text { distancing }\end{array}$ & Frequency & $\boldsymbol{\%}$ & Male & $\boldsymbol{\%}$ & Female & $\%$ \\
\hline Yes & 54 & 18 & 18 & 33.33 & 36 & 66.67 \\
\hline No & 246 & 82 & 148 & 60.16 & 98 & 39.84 \\
\hline Total & 300 & - & - & - & - & - \\
\hline
\end{tabular}

Source: Field Survey, 2020.

Table 6 shows that $82 \%$ of respondents declare that they did not respect the social distancing measure against $18 \%$ who did. Amongst those who have respected the measure, female are more represented with $66.67 \%$ while male represent $333.33 \%$.

\section{Prohibition of public gathering}

Social gathering of more than 50 people banned by the government were intended to control the mass community transmission of Covid-19. Unfortunately, the population of Douala metropolitan town did not comply with this restriction (table7).

Table 7: Follow-up of Instructions on prohibition of public gathering of more than 50 persons in Public Places

\begin{tabular}{|c|c|c|c|c|c|c|}
\hline $\begin{array}{c}\text { Prohibitio } \\
\text { n of public } \\
\text { gathering }\end{array}$ & $\begin{array}{c}\text { Frequenc } \\
\mathbf{y}\end{array}$ & $\boldsymbol{\%}$ & Male & $\boldsymbol{\%}$ & $\begin{array}{c}\text { Femal } \\
\mathbf{e}\end{array}$ & $\boldsymbol{\%}$ \\
\hline Yes & 68 & 22.67 & 26 & 38.23 & 42 & 61.77 \\
\hline No & 232 & 77.33 & 138 & 59.48 & 94 & 40.52 \\
\hline Total & 300 & - & - & - & - & - \\
\hline
\end{tabular}

Source: Field Survey, 2020.

From table 7 , the vast majority of respondents $77.33 \%$ have indicated that they were not following the measure, while $22.67 \%$ are following it. We observed also that men were the careless people about this prohibition $(59.48 \%)$ while women proportion was $40.52 \%$.

Closing of bars, restaurants and entertainment spots after 6 pm

The population of Douala metropolitan town largely followed the closure of bars, restaurants and other entertainment spots after 6 pm (table8).

Table 8: Follow-up of Instructions on closing of bars, restaurants and entertainment spots after $6 \mathrm{Pm}$

\begin{tabular}{|c|c|c|c|c|c|c|}
\hline $\begin{array}{c}\text { Closing } \\
\text { after 6 Pm }\end{array}$ & Frequency & $\boldsymbol{\%}$ & Male & $\boldsymbol{\%}$ & Female & $\boldsymbol{\%}$ \\
\hline Yes & 245 & 81.67 & 139 & 56.73 & 106 & 43.26 \\
\hline No & 55 & 18.33 & 37 & 67.27 & 18 & 32.73 \\
\hline Total & 300 & - & - & - & - & - \\
\hline
\end{tabular}

Source: Field Survey, 2020. 
Table8 shows that $81.67 \%$ of Douala residents comply on closing of bars, restaurants and entertainment spots after $6 \mathrm{pm}$, while $18.33 \%$ did not. The proportion of men who did not comply stand at $67.27 \%$ against $32.73 \%$ for women.

\section{Prohibition of overcrowding in Public transport}

Prohibition of full load during Covid-19 pandemic in Douala metropolitan town was not respected. Public transport continued to charge normally and even overloaded sometimes (table 9).

Table 9: Follow-up of Instructions on prohibition of overcrowding in Public Transport

\begin{tabular}{|c|c|c|c|c|c|c|}
\hline $\begin{array}{c}\text { overcrowding } \\
\text { in Public } \\
\text { Transport }\end{array}$ & Frequency & $\boldsymbol{\%}$ & Male & $\boldsymbol{\%}$ & Female & $\%$ \\
\hline Yes & 98 & 32.67 & 21 & 21.42 & 77 & 78.58 \\
\hline No & 202 & 67.33 & 147 & 72.78 & 55 & 27.22 \\
\hline Total & 300 & - & - & - & - & - \\
\hline
\end{tabular}

Source: Field Survey, 2020.

Table 9 indicates that more than $67.33 \%$ of Douala residents did not comply with the restriction of full load of public transport, while $32.67 \%$ were receptive. Men were more prompt not to respect de restriction (78.58\%) while women represented $27.22 \%$.

\section{The implications of Lock down during COVID-19 in Douala Metropolitan town}

In view to reduce the spread of the virus, the government implemented a partial lockdown whereby quarantine measures were imposed. The outbreak of COVID 19 in the Wuhan province of China has caused tremendous damages to the population of Douala. Economic activities were affected particularly with a sharp drop in domestic consumer demand in most household, and schools ranging from nursery to higher institutions of learning have been closed. Students continued their education through e-learning, television programs and other media alternative like Whatsapp etc. Surveys carried on in 300 respondents in Douala metropolitan town revealed that the inhabitants suffered from unemployment, domestic violence, mental health and delays in other treatments due to social distancing and quarantine measures (table10).

Table 9: Impacts of lockdown on the population of Douala metropolitan town

\begin{tabular}{|c|c|c|c|c|c|c|}
\hline Variable & Frequency & $\boldsymbol{\%}$ & Male & $\boldsymbol{\%}$ & Female & $\%$ \\
\hline Unemployment & 125 & 41.66 & 88 & 70.4 & 37 & 29.6 \\
\hline $\begin{array}{c}\text { Domestic } \\
\text { Violence }\end{array}$ & 80 & 26.66 & 12 & 15 & 68 & 85 \\
\hline Mental Health & 202 & 67.33 & 77 & 38.11 & 125 & 61.89 \\
\hline $\begin{array}{c}\text { Delays in other } \\
\text { treatments }\end{array}$ & 188 & 62.66 & 64 & 34.04 & 124 & 65.96 \\
\hline
\end{tabular}

Source: Field Survey, 2020.
It emerges from table 12 that $41.66 \%$ of respondents indicated that they were unemployed, and among them $70.4 \%$ were men against $29.6 \%$ of women. The table also notes that domestic violence was recorded $(26.66 \%)$ and women were the most affected population with $85 \%$ against $15 \%$ of men.

We also find that the mental health of the population was affected due to confinement with $67.33 \%$ and the proportion of men among them was $38.11 \%$ while that of women was $61.89 \%$.

The impact of Covid-19 on the populations of the city of Douala was severe due to the confinement, some employers have put some staff on technical leave and others workers lost their job, and sometimes even the whole company have been closed. This was felt more in the activities of the tertiary sector. Due to social distancing policies, many workers in restaurants, retail, and other food-related sectors suffer the loss of jobs and income.

The informal sector, which has a large number of workers, have also been hit hard leaving a large part of the population in poverty.

It was also found that households experienced a lot of domestic violence certainly due to unemployment, idleness and the continued presence of household members at home. The conflicts were all over the place, sometimes it was sexual violence by a non-consenting partner. Sometimes it was violence just for the control of the remote control or for the abusive use of the internet connection by the members of the household.

The inhabitants of the city of Douala who were not used to staying in confinement developed a lot of stress. The recommended social distancing was also a source of stress and anxiety and the fear of contamination too.

With the health system of the country being in a fragile state and having very limited facilities and equipment needed to combat the virus, during the period, the attention of healthcare staff was more oriented towards covid-19, the population itself was afraid of going to health facilities for fear of being infected by covid-19 or of seeing their associated disease to covid-19 as a rumor had dominated the whole country and the city in particular. This has created an adverse impact on prenatal care which ensures that pregnant women and developing babies get proper care during the pregnancy period. Also, this has contributed to the delay in treatment of other infectious diseases like tuberculosis, HIV / AIDS and non-infectious diseases like diabetes, cancer etc.

\section{DISCUSSION}

Despite the efforts made by the government through its emergency the covid-19 pandemic still persist. Washing hands with soap and clean water is the single most efficient measure against Covid-19, but for many people it remains an unattainable luxury. Ngueya (2020), in her study Challenges to achieve sustainable development goals in Douala indicated that it cannot be achieved if there is no improvement in 
accessibility on potable water. In her findings $61 \%$ of the population in informal settlement does not have portable water available in their homes [13].

Domestic violence during lockdown was the consequence of social distancing and confinement. The members of house were called upon to share spent more tied time together. It's the same observation made by Lisieux et al.(2020), for those authors, people worldwide have been told by authorities to stay home to reduce the transmission of coronavirus, and social isolation and domestic quarantine can deepen relationships between family members, intensifying intimacy, affective exchanges, personal ties and previous behaviors, thus becoming a period of emotional growth for all involved. On the other hand, it is well-known that most violence against women is perpetrated by family members, and in times of crisis and during epidemics, the number of cases tends to increase. In domestic spaces where this "invisible monster" lives, a range of violations can occur, including intimate partner violence and domestic homicide. Thus, the quarantine forces vulnerable people to share space with their aggressors, which is cause for social alert. The distorted dynamics of power in the homes of abusive or controlling individuals can easily intensify during this crisis, since the abuser has more freedom to act, while the victim's movement is restricted, and continued exposure limits the victim's capacity to cope or seek help.

Unemployment rose in Douala during lockdown as the employers sent their workers on technical leave when they were not sacked. This happened in US in the health where many hospitals and healthcare organizations across the U.S. has been adversely affected by the coronavirus pandemic. A minimum of 150 hospitals in the U.S. had to put employees on leave or lay them off, cut back the salary of doctors or reduce the available benefits [11].

Undoubtedly, COVID-19 has exposed Cameroon's weak health care system,10 April 2020, the country had just four testing laboratories, with three of them in the capital Yaoundé. The country's prime minister, announced plans to transform eight venues into makeshift medical facilities to be used for the treatment and follow-up of COVID-19 patients, but the construction of these makeshift medical facilities, as well as equipping them, has been slow. As of 30 April 2020, none of these makeshift medical facilities was ready to receive COVID-19 cases. Delays also on the treatment of other diseases occur, attention was given more on Covid-19 on the detriment of other diseases. According to Peterson 2020 the increase in the number of COVID-19 positive cases has disrupted the supply chain of pharmaceutical products. Pharmaceutical companies across the world require certain ingredients manufactured in China for the production of drugs. Approximately $60 \%$ of the Active Pharmaceutical Ingredients (API) required all over the world was produced in Chinese factories prior to COVID-19. Many such factories in China was placed under lock down to curb the spread of coronavirus. Many drug companies in the world did not have adequate APIs stored in their warehouse, or even if they did they did not want to sell it to other companies that needed it, or agreed to sell at a steep price. This created a shortage in availability of essential medicines [12].

\section{CONCLUSION}

Cameroon recorded the first case of the Coronavirus on the $6^{\text {th }}$ of March 2020 and thereafter, there was a geometric increase in the number of cases. In response to this, the government announced 13 firm measures in an effort to curb the exponential increase of the Coronavirus cases in the country. Despite the measures the number of cases has continued to increase couple with other unwanted socioeconomic phenomenon's. It was revealed that during lockdown, the city witnessed increases of cases, increase of unemployment, increase in domestic violence, increase of mental health problems, and increase in other infectious diseases and delays in other treatments. The study recommends the effective follow-up of the measures put in place by the government by all the stakeholders, the financial support of enterprises and the population and an aggressive sensitization.

\section{REFERENCES}

[1]. WHO 2020, Director General's opening remarks at the media briefing on COVID-19 - 11 March 2020. https://www.who.int/dg/speeches/detail/who-director-general-sopening-remarks-at-the-media-briefi ng-on-covid-19---11-march2020

[2]. Bradbury-Jones C, Isham $\mathrm{L}$. The pandemic paradox: the consequences of COVID-19 on domestic violence. J Clin Nurs. 2020 Jul;29(13-14):2047-2049. doi: 10.1111/jocn.15296. Epub 2020 Apr 22. PMID: 32281158;PMCID:PMC7262164.

[3]. Telles LEB, Valenc a AM, Barros AJS, da Silva AG. Domestic violence in the COVID-19 pandemic: a forensic psychiatric perspective. Braz J Psychiatry. 2020;00:000-000. http:// dx.doi.org/10.1590/1516-4446-2020-1060

[4]. BBC News. Coronavirus: A visual Guide to the Pandemic. BBC news, March 30 2020. https://www.bbc.co.uk/news/world51235105 .

[5]. B. Chen, H. Liang, X. Yuan, Y. Hu, M. Xu, Y. Zhao, B. Zhang, F. Tian, X. Zhu, Roles of meteorological conditions in COVID-19 transmission on a worldwide scale, MedRxiv (2020), https://doi.org/10.1101/2020.03.16.20037168.

[6]. WHO (2020), Coronavirus disease (COVID-2019) situation reports. Disponible sur https:// www.who.int/emergencies/diseases/novel-coronavirus2019/situation-reports (retrieved 5 june 2020).

[7]. MINSANTE (2020), Cameroun, Rapport de situation COVID-19, $\mathrm{N}^{\circ} 23$, Période du 28 au 30/04/2020, 4p.

[8]. Government of Canada. Non-medical masks and face coverings: about [Internet]. Ottawa, ON: Government of Canada; 2020 [modified 2020 Jun 09; cited 2020 Jun 15]. Available from:https://www.canada.ca/en/publichealth/services/diseases/2019-novel coronavirusinfection/prevention-risks/about-non-medical-masksface-coverings.html

[9]. Telles LEB, Valenc, a AM, Barros AJS, da Silva AG. Domestic violence in the COVID-19 pandemic: a forensic psychiatric perspective. Braz J Psychiatry. 2020;00:000-000. http:// dx.doi.org/10.1590/1516-4446-2020-1060

[10]. https://www.beckershospitalreview.com/finance/49-hospitalsfurloughing-workers-in-response-to-covid-19. html.

[11]. Peterson K Ozili and Thankom Arun. Spillover of covid-19: impact on the global economy. Available at SSRN 3562570, 2020. 
[12]. Mbeutcha Ngueya Anmik Josiane, 2020, Challenges of the sustainable development goals in informal settlements: the case of the goal 3, 6 and 11 in Douala, Littoral Region of Cameroon, master dissertation, University of Bamenda, $173 \mathrm{p}$. 